\title{
A Case with Palmar Fibromatosis with Four Extremity Fibromatosis: Case Report
}

Karasel $\mathrm{S}^{1^{*}}$, Cebeci $\mathrm{D}^{2}$

${ }^{1}$ Physical Medicine and Rehabilitation, Famagusta State Hospital, Famagusta, Cyprus

${ }^{2}$ Dermatology, Famagusta State Hospital, Famagusta, Cyprus

Corresponding Author: Seide Karasel

Address: Physical Medicine and Rehabilitation, Famagusta State Hospital, Famagusta, Cyprus; Tel: +903923650255, +905338707533; E-mail: seidekarasel@hotmail.com

Received date: 05 May 2020; Accepted date: 02 June 2020; Published date: 12 June 2020

Citation: Karasel S, Cebeci D. A Case with Palmar Fibromatosis with Four Extremity Fibromatosis: Case Report. Asp Biomed Clin Case Rep. 2020 Jun 12;3(2):132-34.

Copyright (C) 2020 Karasel S, Cebeci D. This is an open-access article distributed under the Creative Commons Attribution License, which permits unrestricted use, distribution, and reproduction in any medium provided the original work is properly cited.

\section{Abstract}

Palmar fibromatosis (Dupuytren contracture) is the nodule formed on the palmar face of the hand and the contracture of the palmar fascia. It is a clinical disease that causes loss of function resulting in retraction and contracture of the flexor tendons of the hand. Here we summarize a case with a Dupuytren contracture affecting the four extremities and its treatment.

\section{Keywords}

Dupuytren's Contracture, Physical Therapy, Rehabilitation

\section{Introduction}

The nodule formed on the palmar face of the hand and the contracture of the palmar fascia is called palmar fibromatosis (Dupuytren's contracture). The frequency of occurrence after age 65 is bilateral in $24 \%$ and $42-60 \%$ of cases. Many factors are blamed for its etiology. Age, gender, genetic predisposition, hand trauma, excessive use of hands play a role [1-5]. It is also associated with epilepsy, alcoholism, diabetes mellitus, chronic lung disease, HIV, and complex regional pain syndrome [6]. The ratio of men:women is 7:1 in Europe and 1.7:1 in America, and it is more common in men [3,5]. Often bilateral affects the radial side of the hand, affects the $4^{\text {th }}$ and $5^{\text {th }}$ zones, and then the $2^{\text {nd }}$ and $3^{\text {rd }}$ zones. It is more common at the age of 30-40.

Here we summarized a case with a Dupuytren contracture affecting the four extremities and its treatment.

\section{Case Presentation}

A 52-year-old woman presented with a feeling of stretching in the palm and soles and pain in walking on the soles of the feet. He has had complaints for about 3 months; he has not received treatment before. In his history, we learned that he had been using insulin for the past 4 years and had been receiving Type 2 diabetes. He had no other known illness and medication. He stated that he had been working in the field for about 10 years and that he did not do a challenging profession/hobby afterward.

In the physical examination of the musculoskeletal system, there was a restriction in the flexion direction of the palmar bilateral 3 and 4 fingers. The third 
finger was bilateral $0-75$ degrees, the $4^{\text {th }}$ finger bilateral $0-80$ degrees in measurement by a goniometer. It was present on the fingers, movements were limited at the last border (Fig-1 and Fig-2).
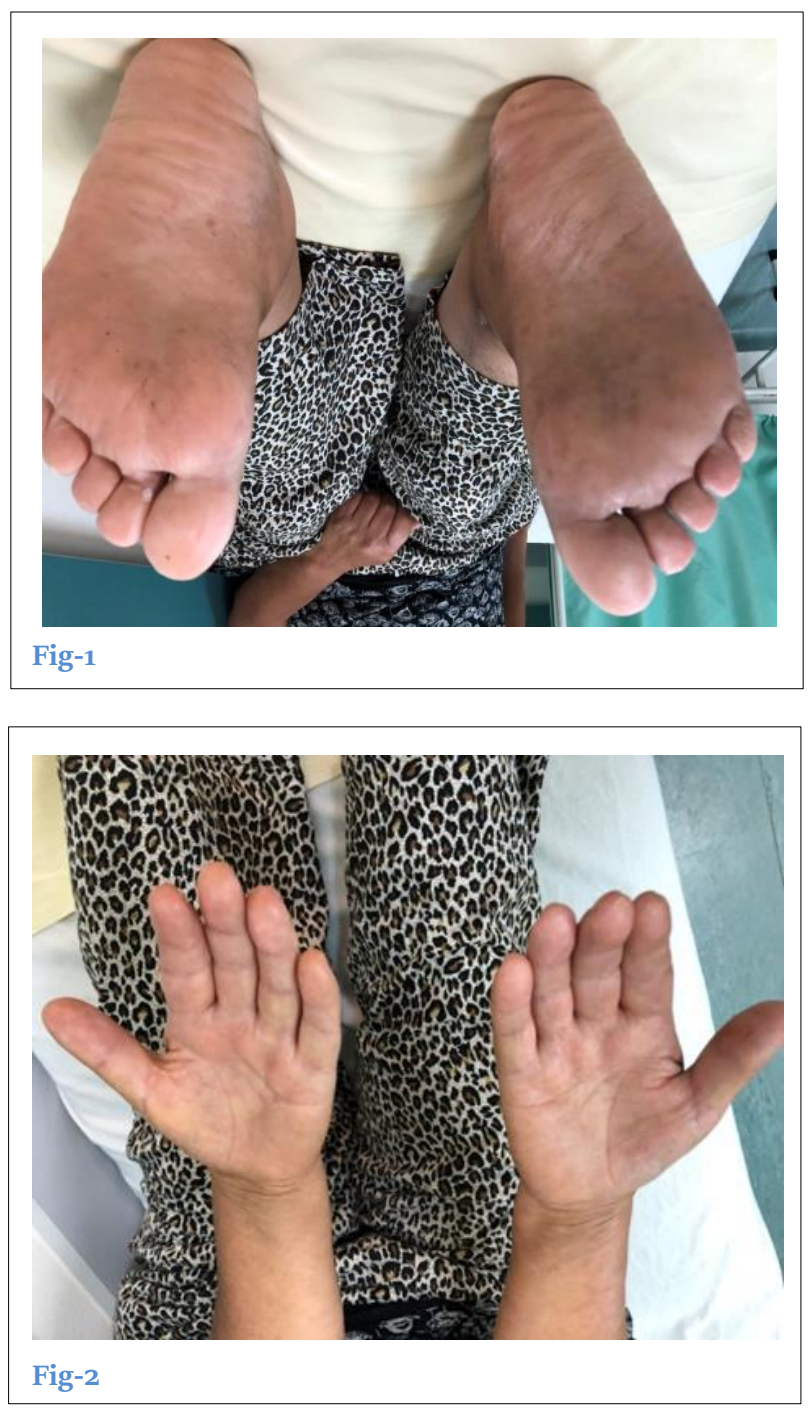

In the treatment, with the application of dorsal splint, hands and feet were given a 15-minute physical therapy program including 20 minutes of paraffin, 5 minutes of 3 watts $\backslash \mathrm{cm} 2$ ultrasound, 20 repetitive joint range of motion, and stretching exercises. The patient did not accept surgical treatment and did not approve of MRI removal. The home exercise program was organized and it was planned to come to the outpatient clinic controls.

\section{Discussion}

Dupuytren contracture (palmar fibromatosis) is evaluated in 5 stages according to Woodruff and
Waldren classification [6]:

Stage-1: MCF has hyperextension in the joint, but the hand is flat on the ground.

Stage-2: There is tension in a single band, only a contract is seen in MCF joint.

Stage-3: There is tension in one band, there is contracture in both MCF joint and PIF joint.

Stage-4: The clinic is in stage 3, but there are contractures in two fingers.

Stage-5: The finger is bent in the palm [7]. In our patient, hands were evaluated as stage $2-3$, and feet as stage 1-2.

The treatment is planned according to the rate of progression of the lesion and the severity of the involvement. Conservative treatments can be preferred in patients with isolated nodules. In most patients whose nodules grow into the cord and lead to contractions, functions are restricted, and aggressive treatment is required. In non-surgical treatments, warming physical therapy modalities, joint range of motion and stretching exercises, and splinting can be applied, including ultrasound [5]. It is recommended to use dorsal splint with slight flexion of the wrist and full extension of the fingers. We also planned a splint in our patient and applied for a 15 -session physical therapy program.

The surgical indication for palmar fibromatosis treatment is flexion contracture of 30 degrees and above in the MCF and PIF joint [4]. For the operation, the contracture in the PIF joint should be expected to reach 30 degrees. Because, in contractures below this degree, the surgery itself can lead to contractures. Flexion contracture is less common in the DIF joint and treatment success is also lower. Fasciotomy, regional and widespread fasciectomy, and dermo fasciectomy are performed in the operation.

Palmar fibromatosis MRI is also a hypoechoic image in the superficial flexor tendons in the metacarpal distal [8].

Palmar fibromatosis is repeated $30-40 \%$ after surgery in the early proliferative period. Because high cellity happens in the proliferative phase. As the lesion 
matures, its cellularity decreases, and its collagen content increases. The recurrence prevalence of the lesion with high collagen content is lower after surgery [9]. Therefore, the diagnosis of palmar fibromatosis is made clinically. If surgical treatment is planned, magnetic resonance imaging is used to see the lesion content. Magnetic resonance images are important in deciding on surgical treatment [10].

\section{Conclusion}

In clinical practice, palmar fibromatosis, which we frequently encounter in geriatric male patients, can affect the functionality and quality of life of patients and is important because of the significant improvement in the functional limitations of the patient with appropriate treatment.

\section{Conflict of Interest}

All authors have read and approved the final version of the manuscript. The authors have no conflicts of interest to declare.

\section{References}

[1] Becker K, Siegert S, Toliat MR, Du J, Casper R, Dolmans GH, Werker PM, Tinschert S, Franke A, Gieger C, Strauch K, Nothnagel M, Nürnberg P, Hennies HC; German Dupuytren Study Group. MetaAnalysis of Genome-Wide Association Studies and Network Analysis-Based Integration with Gene Expression Data Identify New Suggestive Loci and Unravel a Wnt-Centric Network Associated with Dupuytren's Disease. PLoS One. 2016 Jul 28;11(7):eo158101. [PMID: 27467239]

[2] Laskin WB, Weiss SW. Benign fibrous lesions. In: Bogumill GP, editors.Tumors of the hand and upper limb. Edinburgh, Scotland: Churchill Livingstone; 1993. p. 224-43.
[3] Shaw RB Jr, Chong AK, Zhang A, Hentz VR, Chang J. Dupuytren's disease: history, diagnosis, and treatment. Plast Reconstr Surg. 2007 Sep;120(3):44e54e. [PMID: 17700106].

[4] Black EM, Blazar PE. Dupuytren disease: an evolving understanding of an age-old disease. J Am Acad Orthop Surg. 2011 Dec;19(12):746-57. [PMID: 22134207].

[5] Anthony SG, Lozano-Calderon SA, Simmons BP, Jupiter JB. Gender ratio of Dupuytren's disease in the modern U.S. population. Hand (N Y). 2008 Jun;3(2):87-9o. [PMID: 18780o82]

[6] Kuran B. El ve El Bileği Ağrısı Nedenleri ve Muayenesi. In: Beyazova M, Kutsal YG, editors. Fiziksel Tıp ve Rehabilitasyon Kitabı. Cilt 2. Güneş Tıp Kitabevi. Ankara; 2011.p 2035-52.

[7] Verjee LS, Midwood K, Davidson D, Essex D, Sandison A, Nanchahal J. Myofibroblast distribution in Dupuytren's cords: correlation with digital contracture. J Hand Surg Am. 2009 Dec;34(10):178594. [PMID: 19910144]

[8] Morris G, Jacobson JA, Kalume Brigido M, GaetkeUdager K, Yablon CM, Dong Q. Ultrasound Features of Palmar Fibromatosis or Dupuytren Contracture. J Ultrasound Med. 2019 Feb;38(2):387-92. [PMID: 3002766o]

[9] Balaguer T, David S, Ihrai T, Cardot N, Daideri G, Lebreton E. Histological staging and Dupuytren's disease recurrence or extension after surgical treatment: a retrospective study of 124 patients. J Hand Surg Eur Vol. 2009 Aug;34(4):493-96. [PMID: 19675030]

[10] Yacoe ME, Bergman AG, Ladd AL, Hellman BH. Dupuytren's contracture: MR imaging findings and correlation between MR signal intensity and cellularity of lesions. AJR Am J Roentgenol. 1993 Apr;16o(4):81317. [PMID: 8456670] 